\title{
Operating a Virtual Organization (QKC) to Be Effective as a Curatorial Platform
}

\author{
Sheng-Pin Kuan* , Horng-Linn Perng \\ The Chinese Society for Quality, Quality Knowledge Community (CSQ/QKC), Taiwan \\ Received February 10, 2020; Revised April 15, 2020; Accepted April 27, 2020
}

Copyright $\bigcirc 2020$ by authors, all rights reserved. Authors agree that this article remains permanently open access under the terms of the Creative Commons Attribution License 4.0 International License

\begin{abstract}
This is an active and progressive program. Quality Knowledge Community (QKC) is organized by a group of members of Chinese Society for Quality (CSQ) voluntarily. The reason why we call QKC a virtual organization is that it is an informal organization in CSQ; it has no obligation for anybody; its members come from different educational levels, experience, age, job position, geographic; it was stem from QCRG which was a seminar group that had been active for more than 30 years. We have seminars twice a month. In addition, we communicate on various kinds of knowledge websites. Firstly, we clarify our visions, goals and strategies, then we utilize technology roadmap to develop short-term, medium-term and long-term plan of QKC, we name it “QKC Roadmap 2016 2024". We deploy annual plan referring to the roadmap and check it quarterly, and then we build a living mechanism to assure "QKC Roadmap 2016 2024" running effectively, we call it "A Time Stamped PDCA". Through the Internet information trend, we can also collect valuable information based on our own cognition, and then attach new interpretations and meanings to establish a communication and operation platform for innovation and quality management knowledge to identify these documented information and knowledge that improve the quality of life, product quality, service quality, environmental quality, and human quality for global Chinese and people from worldwide who agree with CSQ / QKC to share and apply. This is the new interpretation of CSQ / QKC, the platform of curation era for professional quality knowledge. This article tries to depict how QKC can operate such kind of virtual organization from the stage of forming, storming, norming, to performing.
\end{abstract}

Keywords Quality Knowledge Community (QKC), Chinese Society for Quality (CSQ), Technology Roadmap, PDCA, Curatorial Platform

\section{Introduction}

"In the transformation of generations of nowadays, not only must let the new generation recognize that the development of quality is the gene of improvement due to the needs of human spiritual knowledge, but also must let the old generation know that the development of quality is the induce of prosperity due to the needs of human material satisfaction. In the now of Internet Information Technology, numbers of related hardware and software involve into our life and work, stupid-like old generation feel cannot be adaptive, but smart-like new generation feel cannot be satisfied. The era of Industry 4.0 is coming."

When we talk about information and communication technology (ICT) issues, we often mention the following situations: The major of Taiwan's industrial development is almost focusing on the ICT, shown as Figure 1. In the past 30 years, the ICT industry has dominated the development of our life, work and industry. In our personal age, we really understand the ICT industry was from nothing to something, from something to sufficiency, from sufficiency to convenience, from convenience to rapidity, from rapidity to refinement, from refinement to rarity and so on. As shown in Figure 2: the communication products, from the hand-called call number $\rightarrow$ dial-up call $\rightarrow$ button call $\rightarrow$ BB call $\rightarrow$ mobile phone $2 \mathrm{G}, 3 \mathrm{G} \rightarrow$ smart phone $4 \mathrm{G}$ $\rightarrow 5 \mathrm{G}$; in terms of computer, from punch card input $\rightarrow$ Main Frame $\rightarrow$ PC $\rightarrow$ Notebook computer $\rightarrow$ server; in terms of the network: from the local network to the current Internet. 


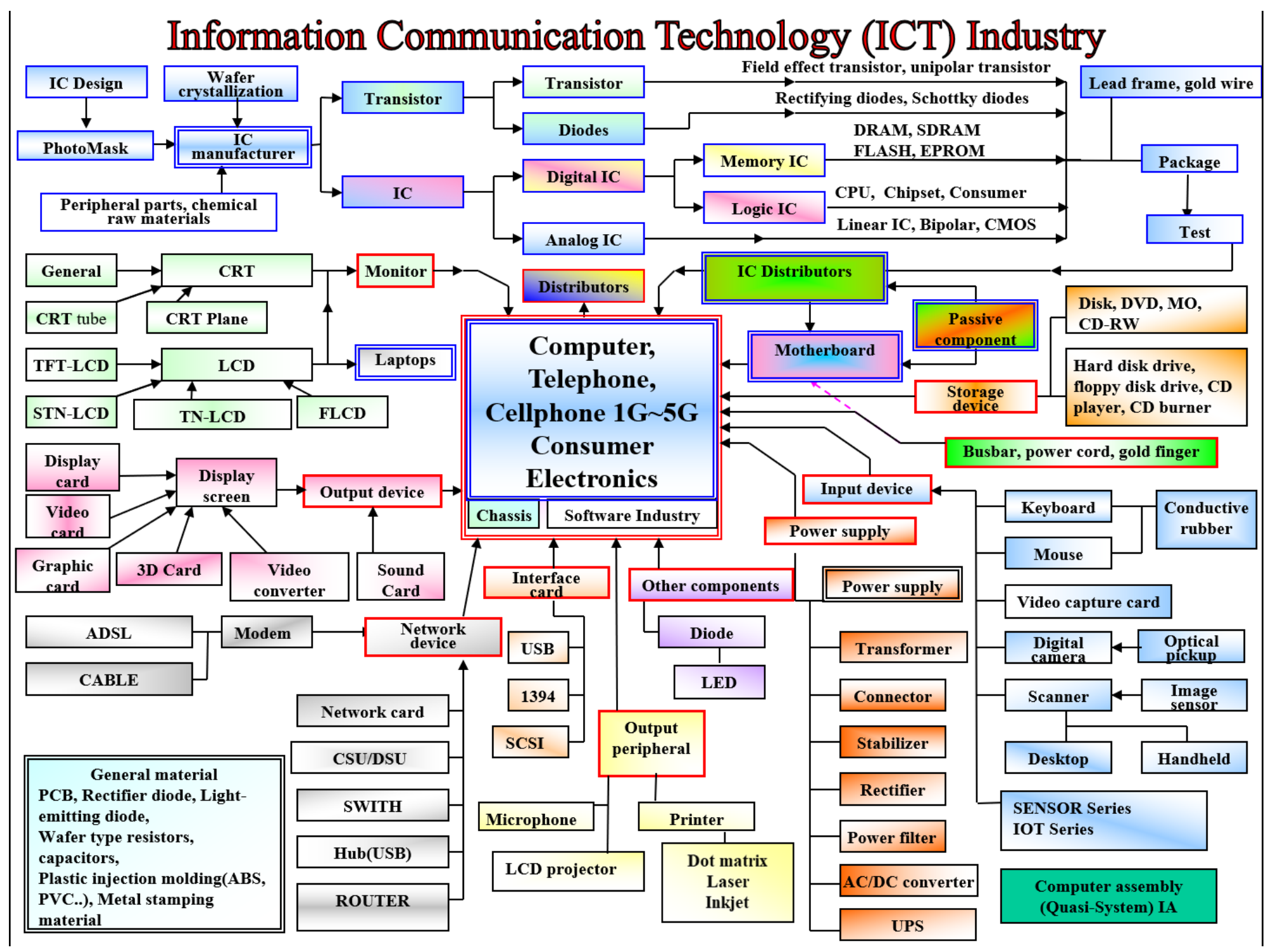

Figure 1. Information Communication Technology (ICT) Industry 


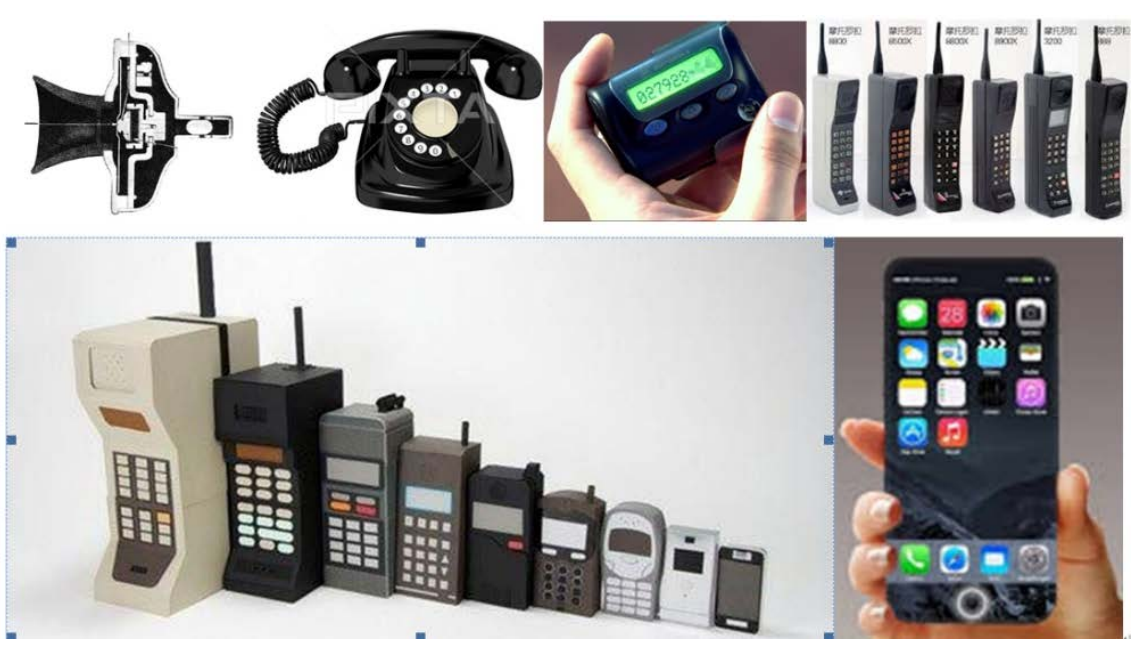

Figure 2. Communication Products

\section{The Internet Thinking}

The book "The Internet Thinking" [1] is the first book in China to systematically explain Internet thinking. It uses 9 major Internet thinking: user thinking, minimalistic thinking, extreme thinking, iterative innovation thinking, traffic thinking, social thinking, big data thinking, platform thinking, cross-border thinking. As shown in Figure 3: Internet thinking.

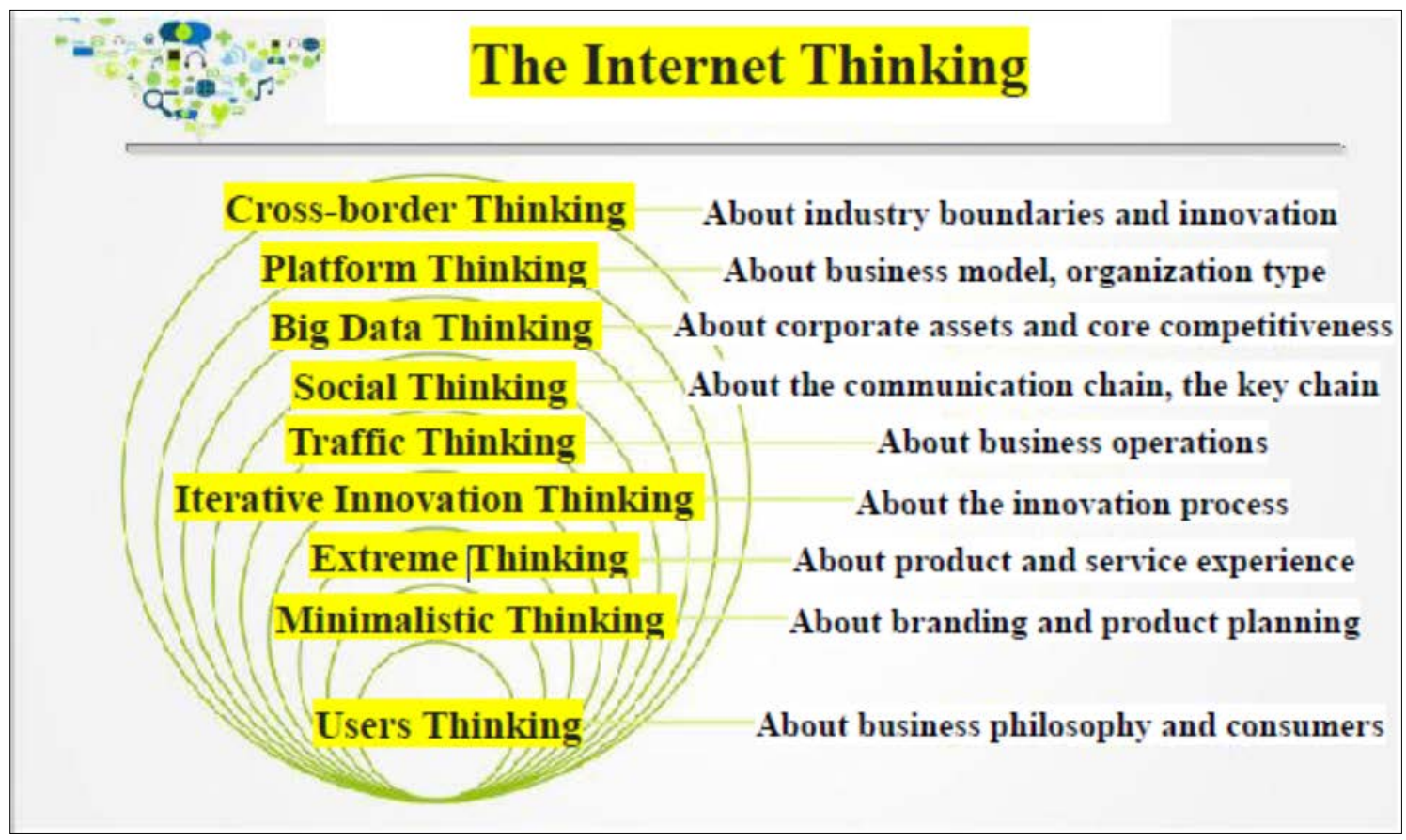

Figure 3. Internet thinking.

Under the guidance of Internet thinking, its integration model will not only be vertical or horizontal value chain integration, but also be innovative with ring-type value integration, such as, strategic planning, business model design, brand building, product development, marketing promotion, organizational transformation, cultural change, and other aspects of the business ring-type value integration, as shown in Figure 4: The Industrial age vs. Internet age. 


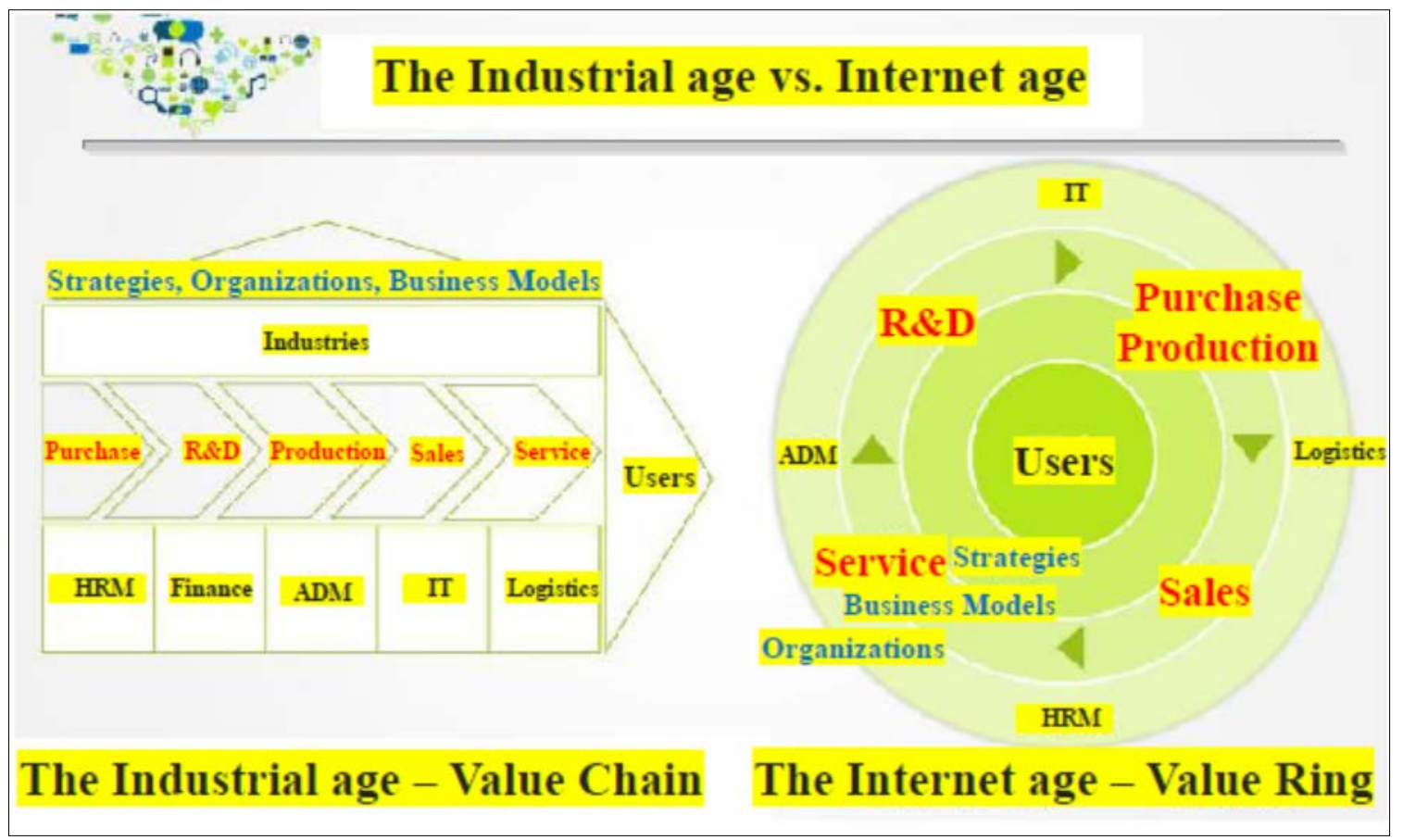

Figure 4. The Industrial age vs. Internet age.

We also always said that: "As for the human spirit needs, also inevitably need to rely on a transparent network of the world, from the message of E-Mail to social networking sites; search from a keyword to find a complete knowledge of documents; from the well-known Scholar's blog sites absorbs the knowledge or experience which they have developed; from the self-built blogs recorded its own feelings of knowledge or experience can share with others. All kinds of documented information and knowledge properly operated and compiled by individuals, communities, society and countries, and systematically identify, create, acquire, capture, apply, share, store, map these documented information and knowledge. By paperless e-book mode built in the existing cloud computing knowledge management system for public access to learning and can enhance the level of knowledge of all people.”

In the future, the development of quality can still develop a variety of professional fields based on the human material and spiritual needs, and the platform provided by Internet information technology.

Since our retirement just over few years, fortunately there is CSQ / QKC platform for us to do something meaningful in the field of quality professional. In the information flow of Internet, the authors of old generation have not disappeared. Instead, in the process of following flow, before retirement we accumulated some skills via utilizing computer software to express our thoughts into articles, the following are several expressive ways which we always applied.
1. The vague idea in our mind, by the expression of words to make it clear;

2. The things what we see and hear, through the expression of words so that it can spread;

3. The esoteric knowledge what we can read, by the expression of words to make it easy to understand;

4. The experience of what we do, through the expression of words so that it can inherit;

5. Make the future of the world trend predictable by written expression;

6. Use our knowledge, skills and services to help others through the expression of words;

7. Do good for your own good and wish good for others, when goodness is shared, the world would turn out good ;

8. Just as you recognize the merits of your own culture, so allow different cultures the same recognition, by doing so, we may reach the world of Great Unity.

Through the Internet information trend, we can also collect valuable information based on our own cognition, and then attach new interpretations and meanings to establish a communication and operation platform for innovation and quality management knowledge to identify, create, acquire, capture, apply, share, store, and map these documented information and knowledge that improve the quality of life, product quality, service quality, environmental quality, and human quality for global Chinese or people from worldwide who agree with CSQ / QKC to share and apply. This is the new interpretation of CSQ / QKC modernization concept-the platform of curation era, shown as Figure 5: The era of curation. 


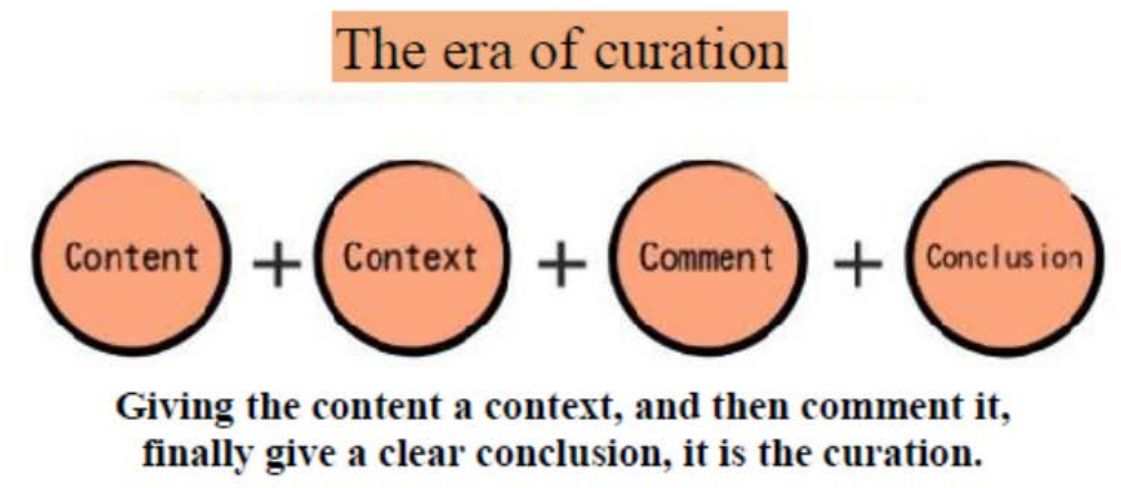

Figure 5. The era of curation

\section{The Era of Curation}

In a broad sense, curation can be defined as "the act of collecting, keeping, interpreting, displaying, and disseminating collectibles (such as art, products, news, data, information, knowledge, etc.)" The process of social development has a long history of curatorial content. The first example of curated content appeared in the form of newsletters. Handwritten newsletters circulate privately among consumers, spreading information from political and economic status to social news, customs, gossip, etc.

Newsletter editors decide what information is most important and relevant to their readers, edit and disseminate that knowledge for public sharing. Newsletters eventually developed into mature newspapers, with editors serving as professional curators for readers to determine which content is most suitable for the masses, most relevant and interesting. With the development of science and technology, it has gradually expanded into Broadcast stations $\rightarrow$ TV stations $\rightarrow$ Internet $\rightarrow$ Internet of Things $\rightarrow$ Internet of Everything, and those who influence the thinking of the masses may be called modern curators, such as station program hosts, Internet celebrities, Internet army, moderators, curators, gardeners, editors. The cloud computing industry is recognized as being divided into three levels: Software as a Service (SaaS), Platform as a Service (PaaS), and Infrastructure as a Service (IaaS). Modern curators may be at the SaaS level, breaking the monopoly of large companies in the past, and now everyone can freely express their creativity and provide a variety of software services via the Internet.

The curatorial content is all-encompassing, it can be a natural person, an event, a drama, a lecture, a document, etc. The appearance of curatorial behavior is a blessing of Internet technology, and curatorial behavior also makes up for the shortcomings of Internet communication. The curator is the emerging role of the Internet world. The question is, who is the curator? and what does the curator curate? In fact, curation is just a concept used to describe the behavior of the Internet world that stirs up topics, leads the trend, and controls the right to speak. The person who promotes this phenomenon is the curator.

In addition to the original professional generated content (PGC), the Internet world has also produced a large number of user generated content (UGC). The two together add up to the key characteristics of the Internet world- Big data.

When users face a large amount of information, it is painful and helpless. Someone must help the public to filter and use the information. Among them, the curator plays a relevant role. Every curator of the Internet world must have a certain subject or expertise in the field of knowledge, and he / she is an active person in the Internet world. He / she filters, understands, reads messages, picks out certain messages for the public, and then rearranging, sorting, proposing observation and reading point of views, so that readers can enter the correct reading context. This is the content, giving context is the first step in curation. Then the curator will give himself / herself a personal interpretation or opinion on these original materials. This is a comment. In the end, the curator must give a clear conclusion to the entire content, events, issues, etc., so far, the preparatory work of the curator has been completed. The curator must successfully promote the above-mentioned curatorial content to online users through the operation on the Internet. This is what happens in the Internet world every day, the key person is the curator. [2]

CSQ / QKC has been implemented as a virtual organization in accordance with the technology roadmap, and has gradually possessed basic operational capabilities on the so-called curatorial platform, including personnel, tools, technology, knowledge, etc. The following methods guide CSQ / QKC in the quality professional field and the operation of the curatorial platform.

The quality professional field required at all levels be well-organized, such as the traditional knowledge technologies listed in the QKC strategy: leadership and management, quality systems, product and process design, product and process control, continuous improvement mechanisms, quantitative methods and tools, and innovation knowledge technology, systematically be 
integrated in a map-like manner to adapt the knowledge required at all levels of the organization, as listed in the following paradigms:

1. Map of quality technology development: Body of knowledge (BOK) + Technical Manual (HDBK) + Personnel Certification Exam. + Capability Maturity Model Integration (CMMI).

2. Map of conformity assessment of quality system: World Trade Organization (WTO) + Technical Barriers to Trade (TBT) + International Standards (ISO) + Industry Standards (IATF).

3. Map of process quality: Process Management + Total Production Maintenance + Quality Engineering + Six Sigma + Lean Production + Toyota Production Management + Process Audit.

4. Map of product quality: Life Cycle Management + System Engineering Management + Functional Safety + Availability Management + Environmental Testing Engineering + Product Audit.

5. Towards an innovation map: Information Communication Technology + Internet Thinking + Cloud Computing + Industry 4.0 + Artificial Intelligence + System Integration.

6. Towards a sustainable success map: Total Quality Management + Operation Management + Policy Management + Daily Management + Risk Management + Value Management + Excellent Business Performance Model.

Apply SaaS, PaaS, IaaS architecture of cloud computing, and change the software in it to knowledge. QKC's curation service $=\mathrm{KaaS}+\mathrm{PaaS}+\mathrm{IaaS}=$ Knowledge as a service + Platform as a service + Infrastructure as a service.

1. Provide knowledge (KaaS): use the knowledge map of the above-mentioned professional fields as content; give context for learning, application, integration, and innovation; give interpretation or opinions, which is a comment; finally, the entire content, events, issues, etc. give a clear conclusion. Document this process into documented information and knowledge to facilitate curation on QKC's curatorial platform.

2. Curatorial platform (PaaS): hold QKC seminars, participate in forum activities (Summit of Chinese Quality, Cross-strait Quality Forum), participate in related seminars, organize education training courses, and hold special lectures. Operate a cloud knowledge management system (KMCloud / QKC knowledge cloud) network service platform, a Reliability Forum (REDI) network service platform, controllable community websites. Publish documented information and knowledge in magazines, periodicals, or books.

3. Set up infrastructure (IaaS): handle QKC reading clubs, build document management centers, develop webpage writing technology, network management technology, database management technology, Microsoft Excel / Word / Power point format and application, presentation skills, audiovisual production (recording and post-production), e-book production technology, etc.

\section{Interpretation of CSQ / QKC Modernization}

Founded in 2004, the Quality Knowledge Community (QKC) is a virtual organization of the Quality Research and Development Committee (QRDC) of CSQ. It is organized by a group of members of CSQ voluntarily, the reason why we call QKC is a virtual organization, it is an informal organization in CSQ; it hasn't any obligation for anybody; its members come from different educational level, experience, age, job position, geography; it was stem from QCRG which was a seminar group had been active for 30 more years. We have seminar twice a month. In addition, we communicate and exchange on the knowledge websites:

http://blog.xuite.net/lingf01;

http://blog.sina.com.cn/lingf02;

http://tw-redi.com/forum.php;

http://www.kmcloud.org/.

community websites: E-mail, Facebook, Line, WeChat, QQ, etc.

During the ten years from 2004 to 2013, under the leading of Lin Gon-Fu, so QKC could operate continuously. QKC's activities and their contributions, "The History of the Quality of Taiwan $2^{\text {nd }}$ Series" had been depicted in detail, so it is not repeated here. [3]

The leader of an organization leads the organization to what level of the configuration, depending on the tacit knowledge accumulated by the leader's over the years and the explicit knowledge formed through the transformation of the data $\rightarrow$ information $\rightarrow$ knowledge, then wisdom is formed by the conversion of the two kinds of knowledge, and leads the interest party with wisdom. Therefore, an organization can establish a vision for the organization's sustainable development in the future; formulate reasonable goals; develop effective strategies; take feasible action plans; monitor and adjust goals, strategies, and plans. As illustrated in Figure 6. 


\begin{tabular}{|c|c|c|c|}
\hline $\begin{array}{c}\text { Phase1: } \\
\text { Planning and } \\
\text { preparation }\end{array}$ & $\begin{array}{c}\text { Phase2: } \\
\text { Visioning }\end{array}$ & $\begin{array}{c}\text { Phase3: } \\
\text { Roadmap development }\end{array}$ & $\begin{array}{c}\text { Phase4: } \\
\text { Implementation } \\
\text { and revision }\end{array}$ \\
\hline
\end{tabular}

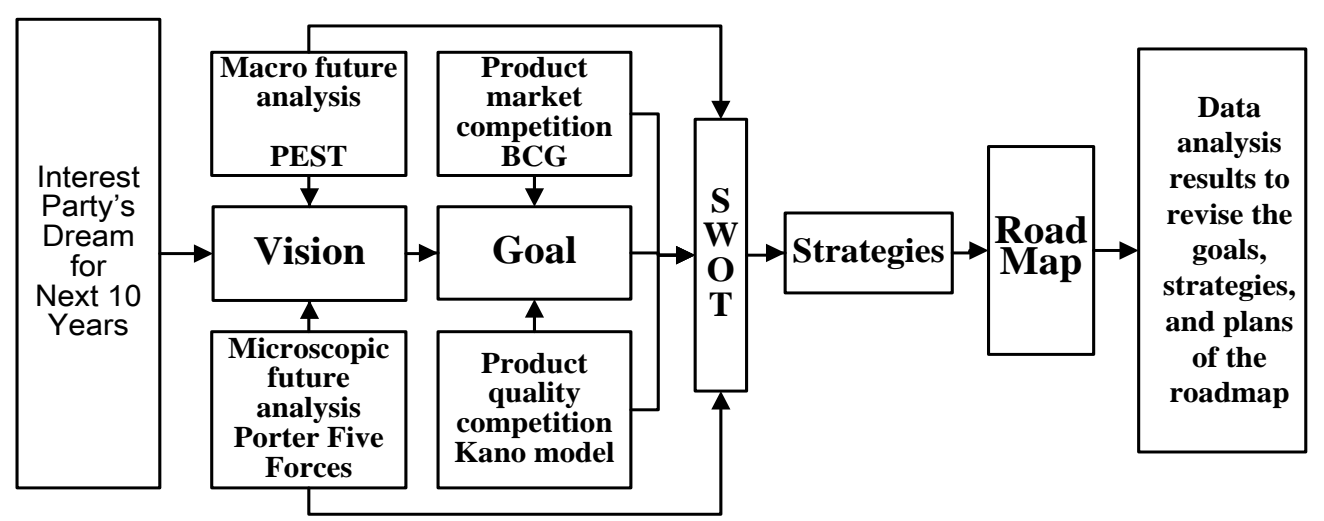

Figure 6. The formation of visions, goals, strategies, and plans

Table 1. QKC Technology Roadmap (2016 2024)

\begin{tabular}{|c|c|c|c|}
\hline Year & 2016、2017、2018 & 2019、2020、2021 & 2022、2023、2024 \\
\hline Goal & $\begin{array}{c}\text { Editing Quality Related Documented } \\
\text { Information and Knowledge } 40 \\
\text { Volumes }\end{array}$ & $\begin{array}{c}\text { Editing Quality Related Documented } \\
\text { Information and Knowledge } 40 \\
\text { Volumes }\end{array}$ & $\begin{array}{c}\text { Editing Quality Related Documented } \\
\text { Information and Knowledge } 40 \\
\text { Volumes }\end{array}$ \\
\hline Milestone & Inheritance Period & Development Period & Sustainability Period \\
\hline $\begin{array}{c}\text { Planning } \\
\text { Items }\end{array}$ & $\begin{array}{l}\text { 1. Integrate CSQ / QKC } \\
\text { stakeholders and other } \\
\text { relevant organizations in a } \\
\text { grouped manner to establish } \\
\text { network communication and } \\
\text { operation platforms. } \\
\text { Prepare Documented } \\
\text { Information and Knowledge } \\
\text { control center. } \\
\text { Prepare the older heritage } \\
\text { book collection plan. } \\
\text { Cooperate with the Secretariat } \\
\text { to assist the CSQ Board } \\
\text { Meeting assigned tasks. } \\
\text { Study Internet of Things, } \\
\text { Industry 4.0 and Big Data } \\
\text { Quality Issues. }\end{array}$ & $\begin{array}{l}\text { 1. Continue to inherit the } \\
\text { planning items for the } \\
\text { inheritance period. } \\
\text { 2. Establish Documented } \\
\text { Information and Knowledge } \\
\text { control center. } \\
\text { Concrete the operation mode } \\
\text { of the CSQ / QKC knowledge } \\
\text { management website. } \\
\text { Officially publish the CSQ / } \\
\text { QKC Excellence Series } \\
\text { Electronic Materials. } \\
\text { CSQ Project Planning } \\
\text { Committee Action Plan. } \\
\text { 6. CSQ Reliability Committee } \\
\text { Action Plan. } \\
\text { QKC Quality Revelation } \\
\text { Column. }\end{array}$ & $\begin{array}{l}\text { Continue to inherit the planning } \\
\text { items for the development } \\
\text { period. } \\
\text { Establish CSQ / QKC Excellent } \\
\text { Management System. } \\
\text { Sustainable Development of } \\
\text { CSQ / QKC Business Model. } \\
\text { Editing history of the } \\
\text { development of the quality of } \\
\text { Chinese people in the world. }\end{array}$ \\
\hline & & & $2020 / 1 / 15$ \\
\hline
\end{tabular}

In 2014, Kuan Sheng-Pin was appointed as the convener of QKC, and Lin Gon-Fu was the executive secretary. From the philosophy, system, technology, methodology and tools of quality management passed down by Lin Gon-Fu, we were doing by learning and thinking. Started to refer to the "Excellent Management Performance Model", "CSQ CQT / CQE / CRE Certification Exam Knowledge Body", "ASQ CQE Certification Exam Knowledge Body" and other references to establish QKC quality knowledge structure and content, prepared the documented information and knowledge by grouping QKC members based on their expertise and interest. At the same time, we applied the "Technology Roadmap" methodology to plan the long-term plan of QKC's visions, goals and strategies for the next decade.

Everything should observe the world's status, see the surrounding situation, know the people's thinking, then can understand the future trends, grasp the precise situation. The principle of the operation of an organization should be based on the trend, to obtain the advantages of future 
development, and then we can do something meaningful. In early 2016, we submitted a "White Paper on Sustainability of CSQ / QKC", in which CSQ / QKC's Visions, Goals, Strategies are the central idea of QKC. We hope that the members of QKC can use this as a consensus to form a belief and ultimately generate strength. It will be revised every year in the future, with the year as version. In September 2015, we presented the article "Operating a Virtual Organization (QKC) to be Effective" at ANQ Congress, Taipei, 2015 to demonstrate our determination. [4] In 2017, Peng Hong-Lin was elected to be the convener of QKC and Kuan Sheng-Pin is the executive secretary, and inherited the visions, goals, strategies, Chinese ways and core values of QKC and expected QKC members to act in accordance with it, wish QKC will be sustainable to continuous operation. Table 1 is 2020 version of QKC Technology Roadmap (2016 2024).

In view of this, the founding purpose, vision, goals, and strategies of CSQ / QKC must also be injected into the curatorial mechanism to make good use of the resources of the Internet world to achieve a curatorial platform in the quality professional field.

\section{Purpose}

CSQ / QKC is a community with the purpose of providing "Systematic Quality Knowledge Service". The core technology is a profound quality knowledge system.

\section{Vision}

Inheriting the guiding principles of "finding practical applications from academia and seeking theoretical practice in action", we are developing QKC to be a curatorial platform of quality knowledge of Chinese society.

\section{Goals}

Establish a curatorial platform for innovation and quality management knowledge, to identify, create, acquire, capture, apply, share, store, map these documented information and knowledge which can enhance quality of life, product quality, service quality, environmental quality, and serve the global Chinese and those who agree with CSQ / QKC to share and apply.

\section{Strategies}

Integrate CSQ / QKC internal and external interest parties and other related organizations by subgrouping way to establish communication and operation curatorial platforms. Subgrouping the quality management knowledge areas which be required at each level of the organization into Management and Leadership, Quality Systems, Product and Process Design, Product and Process Control, Continuous Improvement, Quantitative Methods and Tools, and Innovation Knowledge, by subgrouping QKC members based on their own expertise and interest. We are operating by the living mechanism of QKC, and gradually forming many subgroups with action capabilities. The structure and contents of quality knowledge of each subgroup are shown in Table 2 and Figure 7.

Table 2. The contents of quality knowledge of each subgroup

\begin{tabular}{|c|c|}
\hline Subgroup & Contents \\
\hline Management and Leadership & $\begin{array}{l}\text { Comprehensive quality professional discussion, leadership vision, goals, strategies and } \\
\text { implementation methodology, Quality Ethics, Leadership, Communication, Promotion, Motivation } \\
\text { and other principles and techniques, etc. }\end{array}$ \\
\hline Quality Systems & $\begin{array}{l}\text { Basic introduction to quality system, development process of ISO } 9000 \text { series and current version } \\
\text { content, other ISO management standards, quality system audit, quality cost, personnel training and } \\
\text { training, etc. }\end{array}$ \\
\hline Product and Process Design & $\begin{array}{l}\text { Advanced Product Quality Planning (APQP), Quality Function Deployment (QFD), Failure Mode } \\
\text { and Effect Analysis (FMEA), Reliability and Maintenance Engineering and Management, Project } \\
\text { Management, etc. }\end{array}$ \\
\hline Product and Process Control & $\begin{array}{l}\text { Control Plan, Supply Chain Management (SCM), Measurement and Testing, Sampling Inspection, } \\
\text { Statistical Process Control (SPC), Measurement System Analysis (MSA), Performance } \\
\text { Management (PAC), etc. }\end{array}$ \\
\hline Continuous Improvement & $\begin{array}{l}\text { Quality improvement mechanisms: 5S, QCC, Six Sigma, Preventive and Corrective Action, QC } 7 \\
\text { Tools, 8D, DMAIC, IDDOV, etc. }\end{array}$ \\
\hline Quantitative Methods and Tools & $\begin{array}{l}\text { Basic Statistics, Probability and Probability Distribution, Statistical Inference, Analysis of } \\
\text { Variance, Correlation and Regression analysis, Control Chart, Machine and Process Capability } \\
\text { Study, Design of Experiments (DOE) and Taguchi method, etc. }\end{array}$ \\
\hline Innovation Knowledge & $\begin{array}{l}\text { Quality, Branding and Marketing, ICT, Industry } 4.0 \text { related knowledge and technologies, Big Data, } \\
\text { System Integration, etc. }\end{array}$ \\
\hline
\end{tabular}




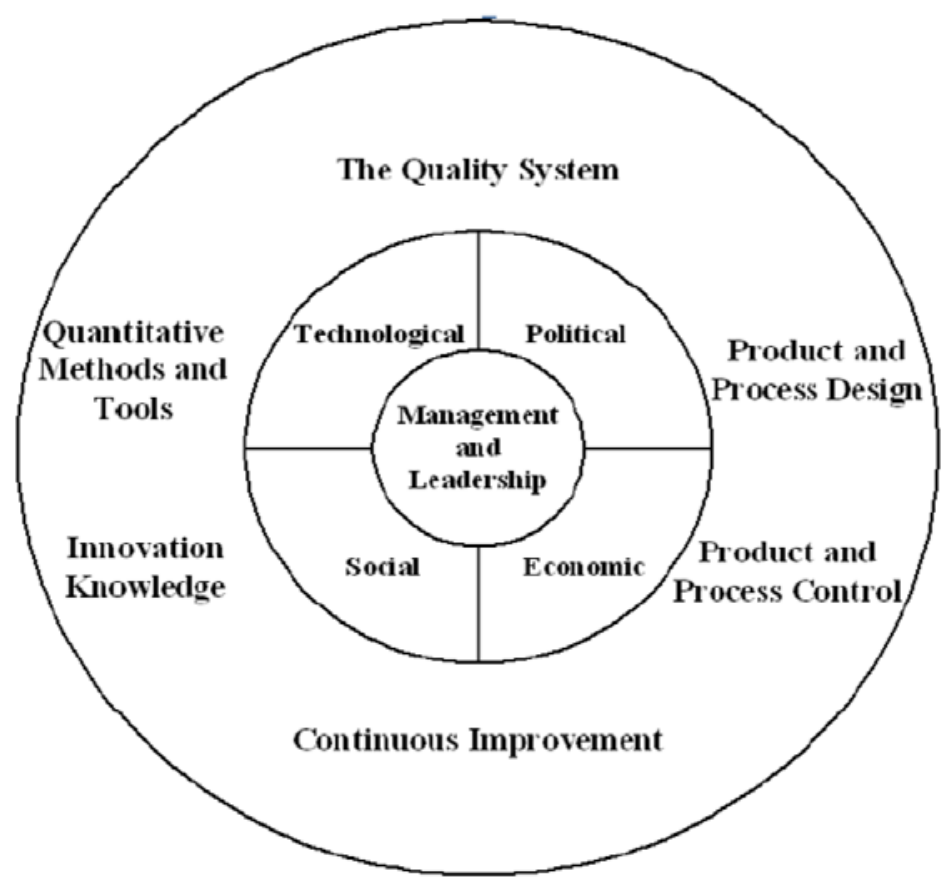

Figure 7. The structure of quality knowledge of each subgroup

\section{The Chinese Way}

Taking the "Great Learning" as the guidance, the "Datong (The Ideal World)" is the implementation of the beginning and ending.

\section{Great Learning}

1. The way of great learning consists in manifesting one's bright virtue, consists in loving the people, and consists in stopping in perfect goodness.

2. When you know where to stop, then you have stability; when you have stability, then you can be tranquil; when you are tranquil, then you can be at ease; when you are at ease, then you can deliberate; when you can deliberate, then you can attain your aims.

3. Things have their roots and branches, affairs have their end and beginning; when you know what comes first and what comes last, then you are near the way.

4. The ancients who wanted to manifest their bright virtue to all in the world first governed well their own states; wanting to govern well their states, they first harmonized their own clans; wanting to harmonize their own clan, they first cultivated themselves; wanting to cultivate themselves, they first corrected their minds; wanting to correct their minds, they first made their wills sincere; wanting to make their wills sincere, they first extended their knowledge; extension of knowledge consists of the investigation of things.

5. When things are investigated, knowledge is extended; when knowledge is extended, the will becomes sincere; when the will is sincere, the mind is correct; when the mind is correct, the self is cultivated; when the self is cultivated, the clan is harmonized; when the clan is harmonized, the country is well governed; when the country is well governed, there will be peace throughout the land.

6. From the king down to the common people, all must regard the cultivation of the self as the most essential thing.

7. It is impossible to have a situation where in the essentials are in disorder and the externals are well-managed. You simply cannot take the essential things as superficial, and the superficial things as essential. This is called, "Knowing the root." This is called "The extension of knowledge."

\section{Datong (The Ideal World)}

When the Great Way (or Principle) prevails, the world is owned by all; they elect men of talents, virtue and ability; they practice honesty, and they cultivate universal peace. People love not only their own parents; they treat with parental care not only for their children. Provision is made so that the aged may live comfortably until their death, so that the able-bodied (those in the prime of life) may find employment, and so that the young may have the means of growing up. The widowers, widows, orphans, childless, and those who are disabled by disease are all sufficiently maintained. Men have their work, and women have their home. They do not like goods to be wasted on the ground, but preserve them, not for themselves alone. They do not like their strength to be wasted in idleness, but spend it, not only for their own benefit. In this way selfish scheming are suppressed and have no chance of arising. Robbers, filchers 
and rebellious traitors do not exist. Hence, the outer doors can be left open, and need not be shut. This is what we call "Datong” (The Ideal World).

\section{Core Value}

Our view of quality is the pursuit of the truth, goodness and beauty of human's affairs, with respect to the elder; with kindness to the younger; with peace to the others; with truth to the doing things.

QKC will follow CSQ / QKC visions, goals, strategies, the Chinese way and core values, interpret as above, and play a role of CSQ's Think Tank as its task; QKC subgroups will cooperate with the Secretariat to assist the Board Meeting of CSQ, and implement QKC technology roadmap (2016 2024), as shown in Table 1, in the long-term; QKC's annual activities will be operated by QKC living mechanism, as shown in Figure 8.

\section{Conclusions}

For the QKC routine seminar, the records from 2013 up to the present day, according to the analysis of these hundreds of seminars, classified by professional fields as shown in Figure 9; classified by methodologies as shown in Figure 10; classified by speakers, as shown in Figure 11. QKC will gradually guide the development of various specialized fields with macro thinking; promote the various specialized technologies in a holistic way; and invite professionals from different industries as core members to participate in the seminars and activities of QKC. From 2016 to 2019, QKC members published articles and books and compiled manuals, as shown in Table 3. [5] In the future, more actively carry out quality professional curatorial activities is necessary.

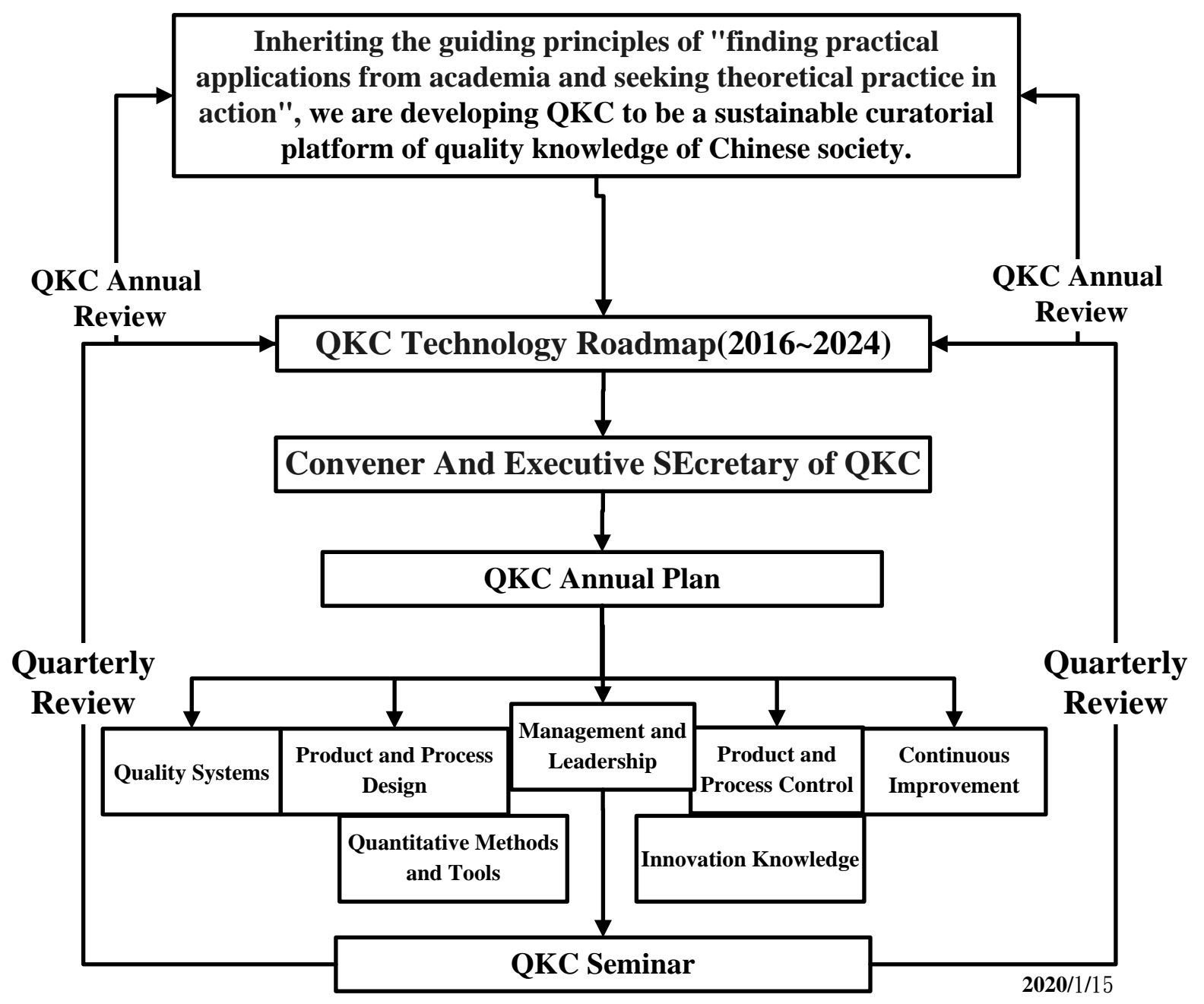

Figure 8. QKC living mechanism 


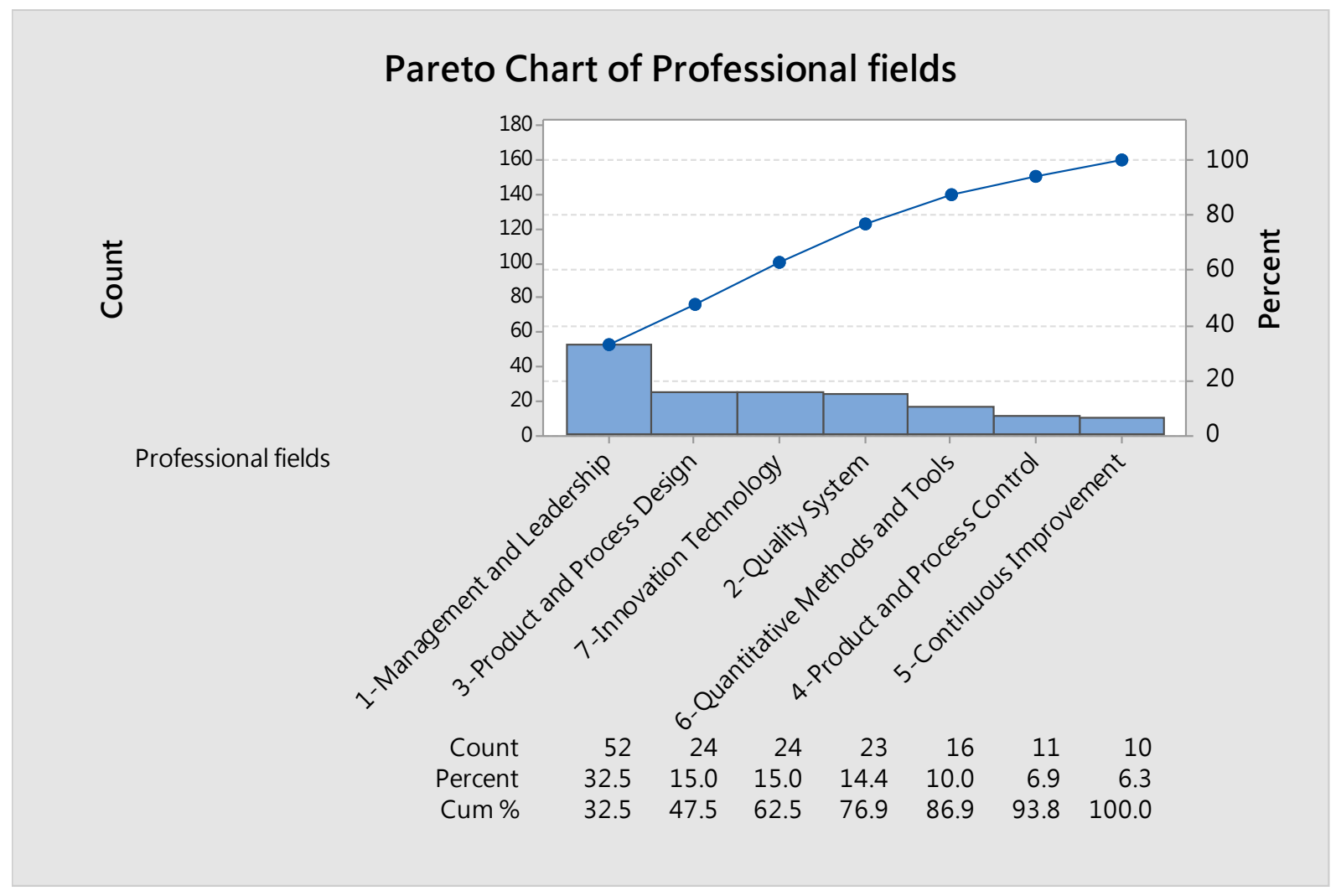

Figure 9. Classified by professional fields

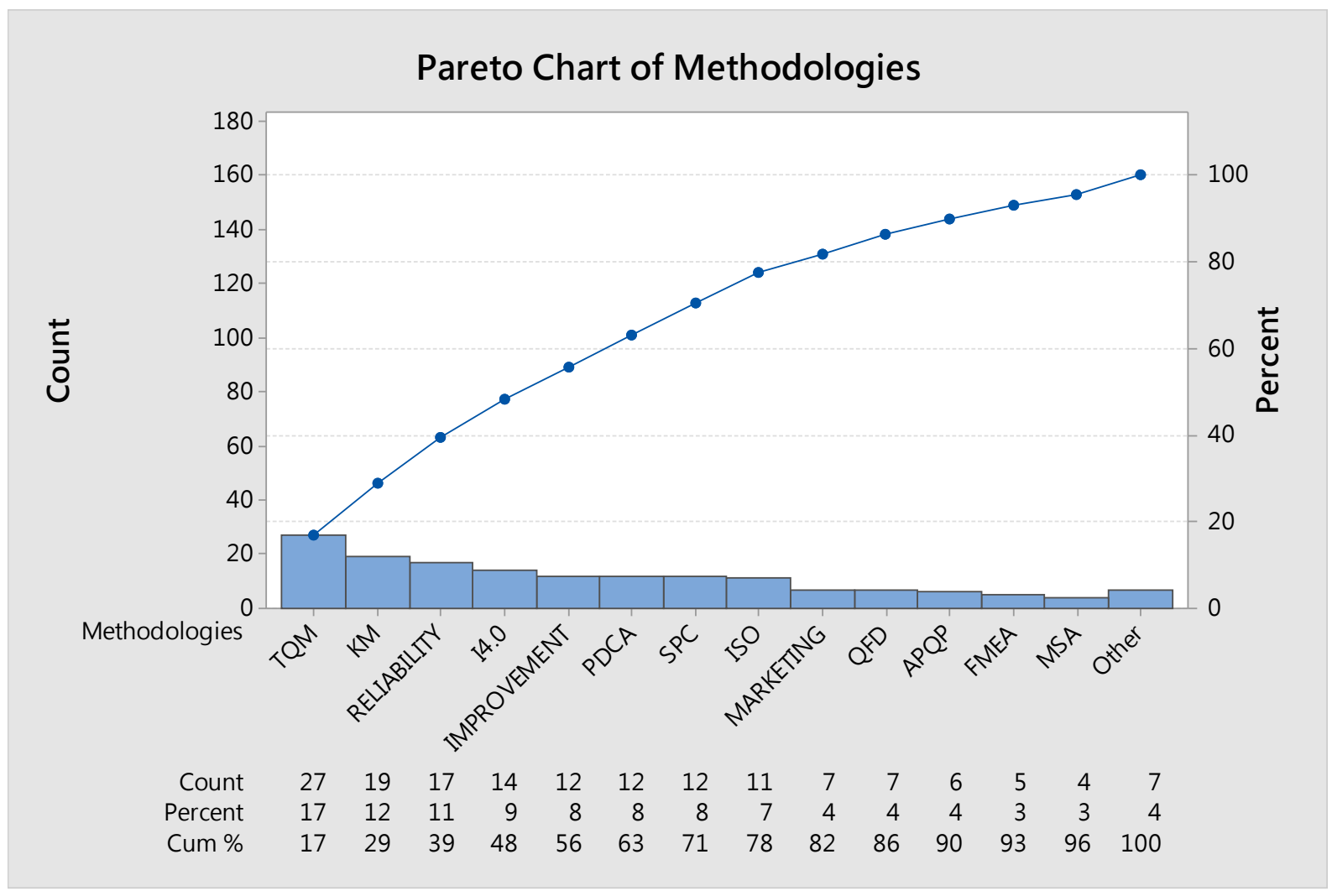

Figure 10. Classified by methodologies 


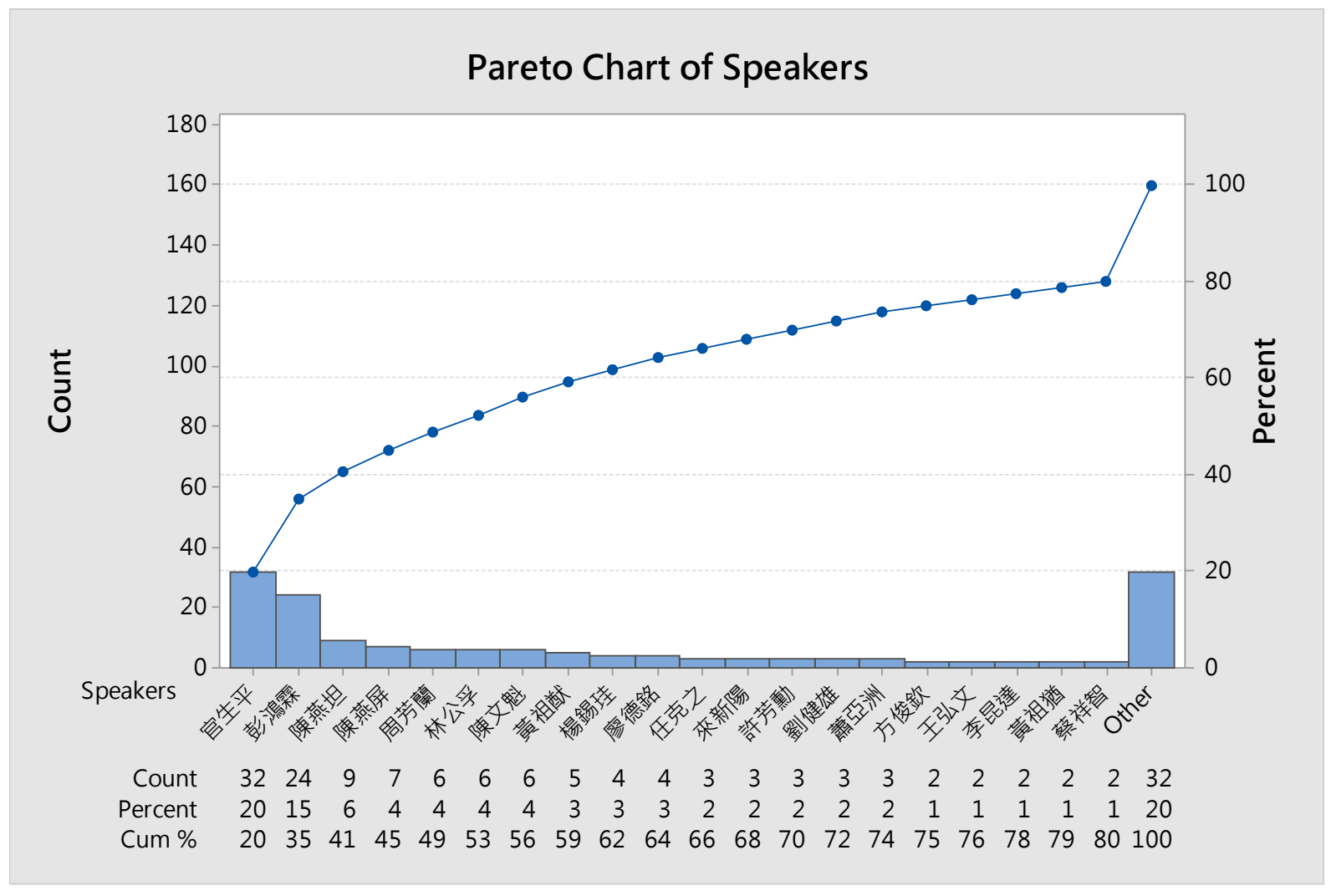

Figure 11. Classified by speakers 
Table 3. 2016 2019 QKC members published articles and books and compiled manuals

\begin{tabular}{|c|c|}
\hline 1. & $\begin{array}{l}\text { Sheng-Pin Kuan (2016): An Improvement Project -Karma Thailand, Universal Journal of Management 4(12): 694-703. } \\
\text { http://www.hrpub.org/journals/jour_archive.php?id=21\&iid=1039 }\end{array}$ \\
\hline 2. & $\begin{array}{l}\text { Fanglan Chou (2016): Exploring through QCC Selected Themes, Proceedings of the fourteen ANQ Congress, Vladivostok, } \\
\text { September 21-22, 2016. }\end{array}$ \\
\hline 3. & $\begin{array}{l}\text { Kuan, Sheng-Pin (2016): Knowledge Should be Owned by Quality Practitioners Under Industry 4.0, Proceedings of the fourteen } \\
\text { ANQ Congress, Vladivostok, September 21-22, } 2016 .\end{array}$ \\
\hline 4. & $\begin{array}{l}\text { Sheng-Pin Kuan (2017): What Roles Can Quality Organizations Play under One Belt One Road, Proceedings of the fifteen ANQ } \\
\text { Congress, Kathmandu, Nepal, September 21-22, } 2017 .\end{array}$ \\
\hline 5. & $\begin{array}{l}\text { 陳燕坦 (2016): Lean TQM—innovating TQM to TVM (Total Value Management), Journal of Mathematics and Statistical } \\
\text { Science, Volume 2016, 400-411. }\end{array}$ \\
\hline 6. & $\begin{array}{l}\text { 王治翰 Wang, Chih-Han, 來新陽 Lai, Hsin-Yang, 官生平 Kuan, Sheng-Pin (2016)：在『一帶一路』框架下品質専業組織 } \\
\text { 可擔負的國際社會責任, 第一屆全球華人品質峰會。 }\end{array}$ \\
\hline 7. & $\begin{array}{l}\text { 王治翰、來新陽、林公孚、官生平、彭鴻霖、陳文魁、盧瑞彥(2017)：華人品質哲學和基礎，第二屆全球華人品質峰會。 } \\
\text { 醫品會訊第十四期轉載(2017-12)，中国质量总 } 448 \text { 期，10/2018，p.12 17. }\end{array}$ \\
\hline 8. & $\begin{array}{l}\text { 王治翰、來新陽、林公孚、官生平、彭鴻霖、陳文魁、盧瑞彥(2017)：現代品質管理-科學、技術、應用整合, 第二屆全 } \\
\text { 球華人品質峰會。 }\end{array}$ \\
\hline 9. & $\begin{array}{l}\text { 王治翰、來新陽、林公孚、官生平、彭鴻霖、陳文鬼、盧瑞彥(2017)：全球華人品質聯盟願景目標策略倡議, 第二屆全 } \\
\text { 球華人品質峰會。 }\end{array}$ \\
\hline 10. & $\begin{array}{l}\text { 王治翰、來新陽、林公孚、官生平、彭鸿霖、陳文魁、盧瑞彥(2017)：工業 } 4.0 \text { 發展過程品質相關的 ICT 知識技術, 第二 } \\
\text { 屈全球華人品質峰會。 }\end{array}$ \\
\hline 11. & 林正國(2017)：領導人的決策品質對企業生存與社會文化的影響，第二屆全球華人品質峰會。 \\
\hline 12. & 陳禮炫(2017)：提昇「價值」的有效作法，第二屆全球華人品質峰會。 \\
\hline 13. & 陳燕坦(2017)：企業管理 vs TQM-為何我們會輸？第二屆全球華人品質峰會。 \\
\hline 14. & 黄祖猶(2017)：IATF 16949:2016 稽核缺失探討與其相關標準解說，第二屆全球華人品質峰會。 \\
\hline 15. & 陳科引(2017)：寓藝術於環保生態，第二屆全球華人品質峰會。 \\
\hline 16. & 陳姝㮆(2017)：生產製程管理實務，第二屆全球華人品質峰會。 \\
\hline 17. & 翁辰修，鄧璍鈞(2017)：製藥工廠品質管理新焦點，第二屆全球華人品質峰會。 \\
\hline 18. & Sheng-Pin Kuan (2018): The Chinese Way TQM, LAP LAMBERT Academic Publishing (2018-02-20). \\
\hline 19. & Sheng-Pin Kuan (2018): Three Old Pieces of TQM, LAP LAMBERT Academic Publishing (2018-06-29). \\
\hline 20. & $\begin{array}{l}\text { Kuan, Sheng-Pin, Perng, Horng-Linn (2018): Knowledge should be owned by Quality Practitioners in the IT Age, Proceedings of } \\
\text { the 16th ANQ Congress, in Almaty, Kazakhstan, September 19-20, } 2018 .\end{array}$ \\
\hline 21. & $\begin{array}{l}\text { Kuan, Sheng-Pin, Perng, Horng-Linn (2018): The Chinese Way Total Quality Management, Proceedings of the 16th ANQ } \\
\text { Congress, in Almaty, Kazakhstan September 19-20, } 2018 .\end{array}$ \\
\hline 22. & $\begin{array}{l}\text { Wang, Chih-Han, Lai, Hsin-Yang, Kuan, Sheng-Pin (2018): What Roles Can Quality Organizations Play under One Belt One } \\
\text { Road? SQI Yearbook 2017, p.61 66, 04/2018. }{ }^{[6]}\end{array}$ \\
\hline 23. & 2018-Q4-W1-QKC 品質啟示錄專欄-開欄白 \\
\hline 24. & 2018-Q4-W1-Opening Remark \\
\hline 25. & 2018-Q4-W2-QKC 品質啟示錄專欄-品質哲學與基礎 \\
\hline 26. & 2018-Q4-W2-Quality Philosophy and Foundation \\
\hline 27. & 2018-Q4-W3-QKC 品質啟示錄專欄-華人品質哲學與基礎 \\
\hline 28. & 2018-Q4-W3-Chinese Quality Philosophy and Foundation \\
\hline 29. & 2018-Q4-W4-QKC 品質啟示錄專欄-認知的品質 \\
\hline 30. & 2018-Q4-W4-Quality of Cognition \\
\hline 31. & 2018-Q4-W5-QKC 品質啟示錄專欄-認知的品質補充 \\
\hline 32. & 2018-Q4-W6-QKC 品質啟示錄專欄-知識的品質 \\
\hline 33. & 2018-Q4-W6-Quality of Knowledge \\
\hline 34. & 2018-Q4-W7-QKC 品質啟示錄專欄-資訊的品質 \\
\hline 35. & 2018-Q4-W7-Quality of Information \\
\hline 36. & 品質哲學和基礎(Quality Philosophy and Foundation) \\
\hline 37. & 品質管理-科學_技術_應用整合(Quality Management-Integration of Science, Technology and Application) \\
\hline 38. & 策略規劃與創新(Strategic planning and Innovation) \\
\hline 39. & 領導及團隊問題分析與解決(Leadership Principles and Techniques) \\
\hline 40. & 品質成本(Quality Cost)-2018-8-28 \\
\hline
\end{tabular}




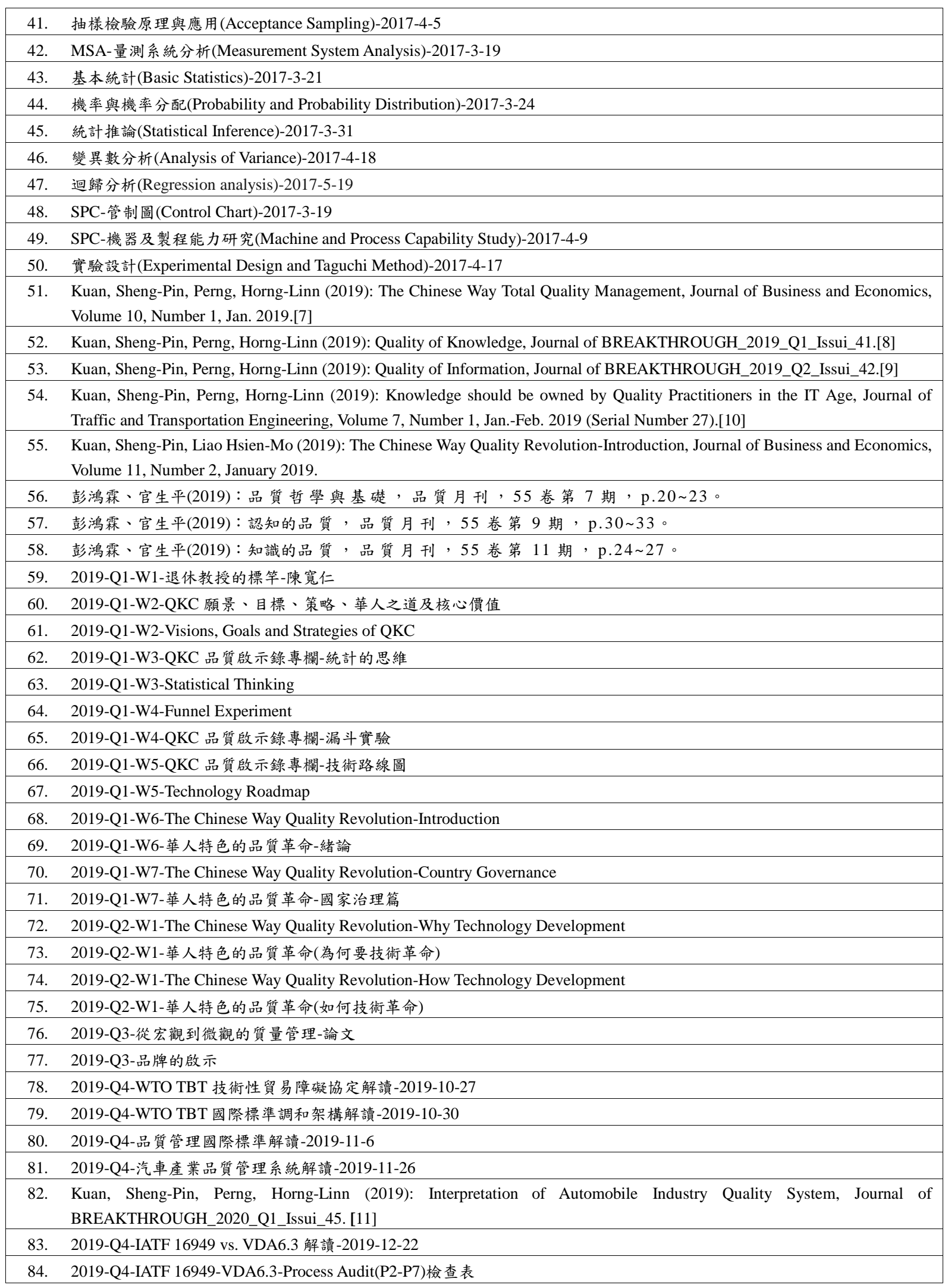




\section{REFERENCES}

[1] Zhao Dawei (2014): The Internet Thinking, Mechanical Industry Press, http://www.sanmin.com.tw/product/index/9 9w155k6s104d84r107v69u104t125eimxwjz1010zlu

[2] [ 何 飛 鹏 ] 策展人策展什麼? https://www.bnext.com.tw/article/26700/BN-ARTICLE-26 700

[3] Lin Gon-Fu (2015) : Development and Prospect of Quality Knowledge Community, "the History of the Quality of Taiwan $2^{\text {nd }}$ Series”, p.40 46, CSQ.

[4] Sheng-Pin Kuan, Horng-Linn Perng (2015): Operating a Virtual Organization (QKC) to be Effective, Proceedings of the thirteenth ANQ Congress, Taipei, September 23-24, 2015.

[5] 2019-Q1-W2-Visions, Goals and Strategies of QKC, http://www.kmcloud.org/

[6] Wang, Chih-Han, Lai, Hsin-Yang, Kuan, Sheng-Pin (2018): What Roles Can Quality Organizations Play under One Belt One Road? SQI Yearbook 2017, p.61 66, 04/2018.

[7] Kuan, Sheng-Pin, Perng, Horng-Linn (2019): The Chinese Way Total Quality Management, Journal of Business and Economics, Volume 10, Number 1, Jan. 2019.

[8] Kuan, Sheng-Pin, Perng, Horng-Linn (2019): Quality of Knowledge, Journal of BREAKTHROUGH_2019_Q1_Iss ui_41.

[9] Kuan, Sheng-Pin, Perng, Horng-Linn (2019): Quality of Information, Journal of BREAKTHROUGH_2019_Q2_Iss ui_42.

[10] Kuan, Sheng-Pin, Perng, Horng-Linn (2019): Knowledge should be owned by Quality Practitioners in the IT Age, Journal of Traffic and Transportation Engineering, Volume 7, Number 1, Jan.-Feb. 2019 (Serial Number 27).

[11] Kuan, Sheng-Pin, Perng, Horng-Linn (2019): Interpretation of Automobile Industry Quality System, Journal of BREAKTHROUGH_2020_Q1_Issui_45. 